\title{
FROM NATURE TO NURTURE: THE HISTORY OF SACRAMENTO'S URBAN FOREST
}

\author{
by E. Gregory McPherson and Nina Luttinger
}

\begin{abstract}
Over the course of 150 years, a combination of cultural and natural processes drove Sacramento's transition from City of the Plains to the City of Trees. This paper describes how the many authors of Sacramento's treescape have affected the health, management, and public perception of the city's trees. Local government directed early street and park tree plantings and banned problem tree species by ordinance. During the first half of the 20th century, participation in street tree planting and preservation by groups such as the Chamber of Commerce, Boy Scouts, Science Teachers Association, and "tree enthusiasts" raised public awareness and civic pride. The large trees shading city streets became a community icon, frequently described as the "crowning jewel of Sacramento." More recently, concern about street tree health associated with declining funds for municipal tree care has spawned new partnerships that involve trained volunteers in Dutch elm disease control, residents in energy-conserving yard tree planting, and a public task force in developing policy recommendations to perpetuate Sacramento's legacy as the City of Trees.

Keywords. Urban forest, forest history, forest management, historical development
\end{abstract}

Trees and other vegetation in cities comprise the urban and community forests where most Americans live. These forests are the result of multiple cultural and ecological factors acting in concert over time. As such, urban forest history can be viewed as a narrative that reflects the interactive cycling of natural and cultural processes in a given urban area. Natural factors, such as Sacramento's hot, dry summers and periodic windstorms, have shaped perceptions concerning the benefits and risks of large, old shade trees. Cultural factors, such as the city's physical development, have affected the space available for vegetation and its distribution (Sanders 1984). Technological advances in areas such as pest control, air conditioning, and transportation have influenced attitudes regarding the value of trees, as well as their preservation and management. Public involvement has shaped policies and management practices.
This study is based on a survey of written and visual materials, as well as interviews with local residents. Our sources, both primary and secondary, include local histories, newspaper articles, travel descriptions, maps, prints, and photographs. Similar types of sources have been used to describe the neoclassical origins of modern urban forests and to trace the evolution of urban vegetation in Tucson, Arizona; Oakland, California; and Chicago, Illinois (McPherson and Haip 1989; Lawrence 1993; McPherson et al. 1993; Nowak 1993). We chose to study the historical development of Sacramento's urban forest to enhance our understanding of its transition from City of the Plains, as it was known during the 19th century, to its more current sobriquet as the City of Trees (Kane and Alexander 1979).

In particular, we trace the changing role of public participation and support for the municipally managed component of Sacramento's urban forest. Although the city's street and park trees account for only $9 \%$ of the total tree population today (McPherson, in press), nearly 150 years of management has resulted in policies, ordinances, and partnerships that have influenced the entire urban forest. In reality, the distinction between public and private vegetation is ambiguous. Residents adopt public trees as their own, and cities often remove diseased, private trees that threaten street and park trees, as well as other privately owned trees. By identifying the factors and persons responsible for Sacramento's treescape, we hope to provide information that will prove useful for the sustainable design of tomorrow's urban forest. By understanding the picture we see today and the story behind its development, we hope to be better equipped to make projections, create management plans, and set priorities for future urban forestry activities. 


\section{Geography and Presettlement Vegetation}

The city of Sacramento lies in the Sacramento Valley, bounded by the Sierra Nevada mountain range to the east and the coastal range to the west (Figure 1). The terrain is fairly flat except for areas where the American and Sacramento rivers and their tributaries have created stream banks. The climate is Mediterranean, characterized by hot, dry summers and cool, rainy winters. The growing season in Sacramento averages 282 days (base $0^{\circ} \mathrm{C}$ ). Although average annual rainfall in Sacramento is $465 \mathrm{~mm}$ (18.3 in.), only about $1 \%$ occurs in June, July, and August (Tugel 1993). The annual water requirement for a typical irrigated Sacramento landscape is $1,170 \mathrm{~mm}$ (46 in.).

In the early 1850 s, Sacramento was known as the City of the Plains because grassland communities covered most of the valley (Dobbins 1980). Two types of forest communities were present: blue oak woodland and riparian forest (Heritage Oaks Committee 1977). The blue oak woodland occupied upland areas and was characterized by sparse to dense stands of blue oak (Quercus douglasii) with interior live oak ( $Q$. wislizenii) and foothill pine (Pinus sabiniana) in-

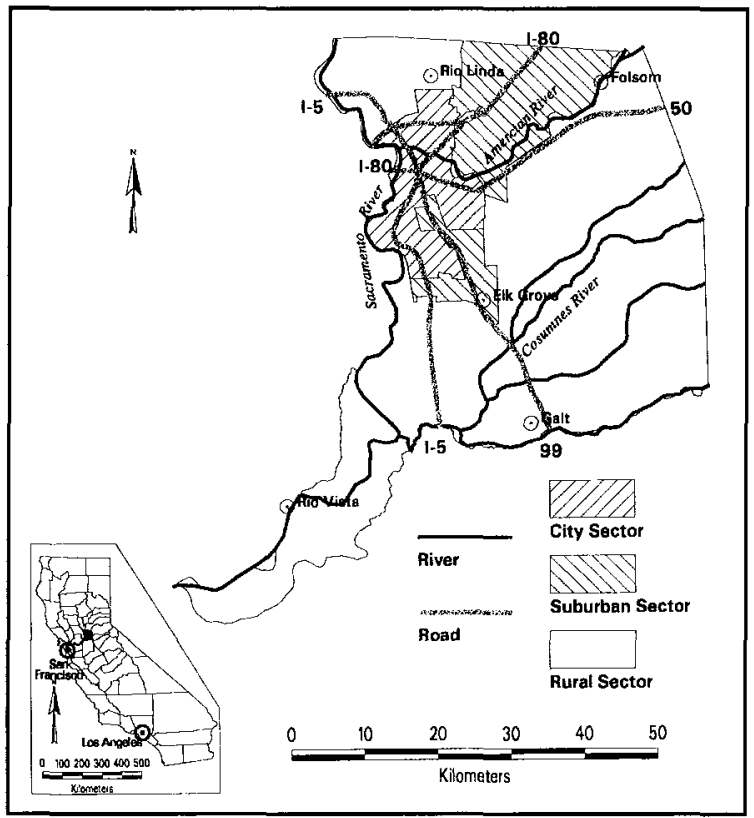

Figure 1. The Sacramento Urban Forest Ecosystem Study site is located in California's Central Valley. terspersed. Riparian forests extended in bands along river courses and associated bottom lands. Early successional communities were dominated by willow (Salix spp.) and Fremont cottonwood (Populus fremontii), while trees such as Oregon ash (Fraxinus latifolia), California black walnut (Juglans hindsii), western sycamore (Platanus racemosa), and valley oak ( $Q$. lobata) were present in later-stage forests.

Before Captain John Augustus Sutter established the first permanent Anglo settlement in 1839 , explorers marveled at the region's unique native arboreal growth. During Captain Belcher's exploration up the Sacramento River in 1837, he noted the lush riparian forest:

The marshy land now gave way to firm ground, preserving its level in a most remarkable manner, succeeded by banks well wooded with oak, planes, ash, willow, chestnut, walnut, poplar, and brushwood.... [W] ithin, and at the verge of the banks, oaks of immense size were plentiful. These appeared to form a band on each side, about three hundred yards in depth, and within they were to be seen disposed in clumps, which served to relieve the eye, wandering over what might otherwise be described as one level plain or sea of grass (Pierce and Winslow 1979).

\section{From Native to Urban: $1848-1900$}

Following the 1848 discovery of gold in the nearby Sierra foothills, Sacramento experienced rapid growth. Interestingly, early Sacramentans seemed to hold two conflicting views of local natural resources. On one hand, many had come to the region for exploitative reasons-to extract gold or to consume land for agriculture. For these residents, nature was commonly perceived as an obstacle, something to be conquered. On the other hand, people seemed to value trees, insofar as they served some utilitarian purpose. For example, trees growing along the river's edge in the city were used to tie down river boats, to the extent that most of these trees were dead by as early as 1850 . However, many early residents also had the rational goal of creating a safe and healthful environment within the incipient city and viewed trees as valuable for this purpose.

As exemplified by traveling journalist Bayard Taylor's descriptions, visitors in 1850 were al- 


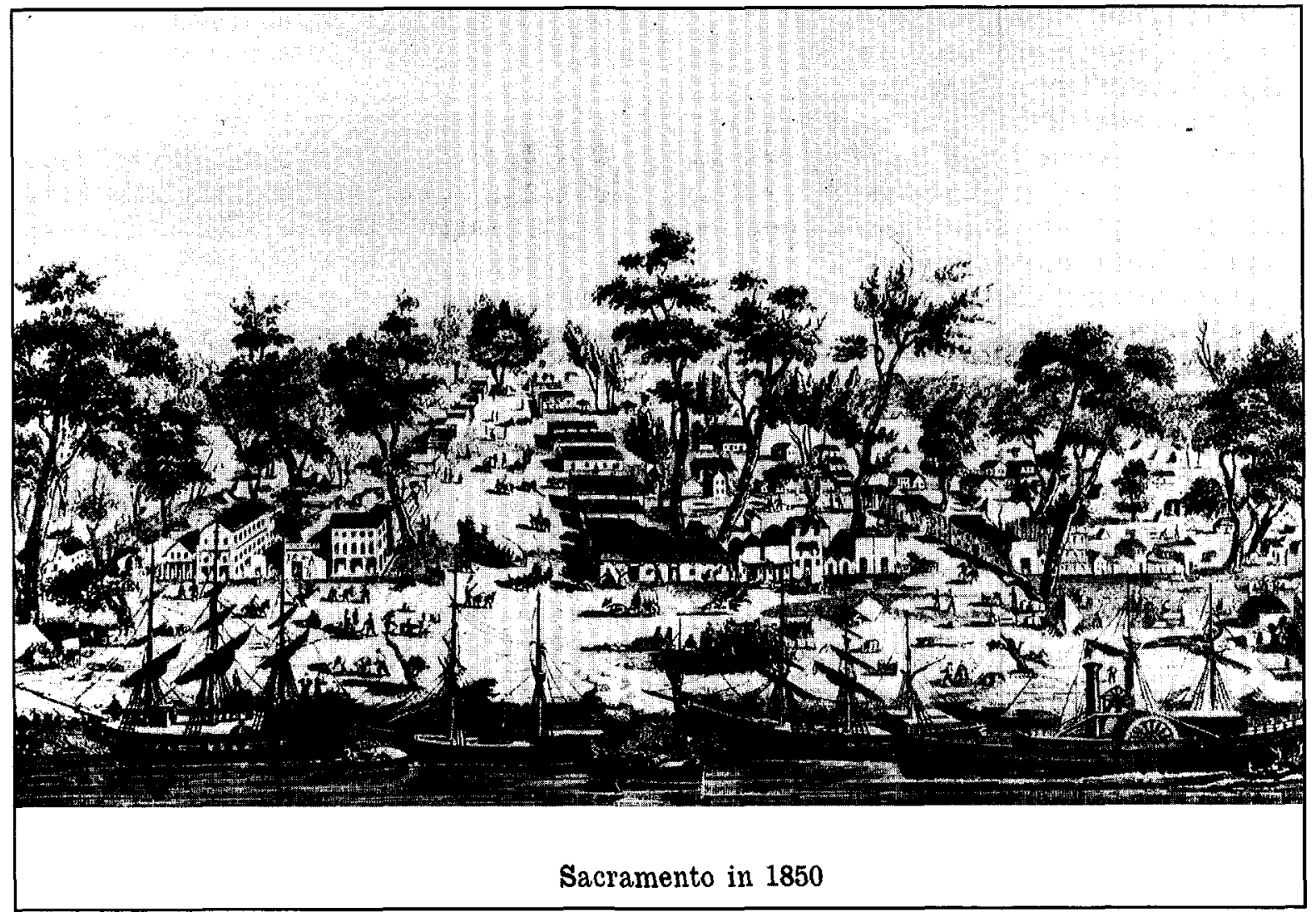

Figure 2. Native trees such as cottonwoods, oaks, and sycamores were preserved as the city became established. These preexisting trees afforded a generous shade to early settlers during scorching summers ( 1850 lithograph by Baker, courtesy of the C.N. Silsbee collection, Sacramento Archives and Museum Collection Center [SAMCC], City of Sacramento).

ready taking special note of the forest that existed within this city. Description of the great size of many of the trees indicates that the trees existed before the city became incorporated and had been preserved as people built around them (Figure 2). Taylor's words demonstrate the early value of shade relief, certainly one of the prime motivations behind tree-mindedness. However, he also identifies the short-term, exploitative mentality that led to the demise of some of the largest trees, presumably caused by transients brought in by the gold rush:

The original forest trees, standing in all parts of the town, give it a very picturesque appearance. Many of the streets are lined with oaks and sycamores, six feet in diameter, and spreading ample boughs on every side. The emigrants have ruined the finest of them by building camp- fires at their bases, which, in some instances, have burned completely through, leaving a charred and blackened arch for the superb tree to rest upon.... The destruction of these trees is the more to be regretted as the intense heat of the summer days, when the mercury stands at $120\left[{ }^{\circ} \mathrm{F}\right]$, renders their shade a thing of absolute necessity (Taylor 1949).

Park development and early tree planting. Preservation of existing trees was concurrent with early park planning. In 1849, Sutter's son John, Jr., took 1,000 ha $\left(4 \mathrm{mi}^{2}\right)$ of his father's land grant and designated it the town of Sacramento. He laid out a 900-block grid of streets, sold lots for $\$ 200$ to $\$ 500$, and designated 12 public squares within the city. This designation demonstrates an early commitment to set aside some of the city's land from development and to preserve native, exist- 
ing trees. Although several of the squares were eventually used as sites for public buildings, eight became public parks (McClatchy High School 1948). Until creation of a board of parks in 1911, some of these public squares were leased temporarily for purposes such as grazing (Henley 1995). Such agreements provided a source of revenue to the city as it developed park plans, which served to keep weed problems under control.

Early urban forestry activities were managed through city council ordinances for specific tree plantings and removals. For example, ordinances directed the planting of willow trees (Salix spp.) on the levee from 20th Street to its eastern terminus in 1853, and in 1865, ordered the planting of 50 locust trees (Robinia spp.) in the city plaza (City Council Minutes [CCM] 1853, 1865). Orders for trees were issued by the city council, put out for bid by the city clerk, and awarded to the lowest bidder. Input and recommendations came from the street commissioner (although his job was primarily focused on street planking, widening, and maintenance), but all final decisions rested with the city council.

Evidence of local appreciation for street tree planting dates to 1855 . "Our citizens have a mania for planting trees. There is hardly a street in the suburbs that in a few years will not be beautifully shaded by rows of cottonwood and locust trees" (Daily Democratic State Journal 1855). Naturally occurring cottonwoods were favorites because they were easily grown and provided generous shade. However, in 1857-just weeks after launching the Sacramento Bee-editor James McClatchy wrote in his paper:

In very numerous instances luxuriant cottonwoods that have been flourishing for 3 or 4 years past are being rapidly leveled by the ax, and maple, locust, and china trees substituted in their place, which is right and proper, as cottonwoods are very noxious after a few years growth, yet they should not be removed until the others are old enough to give shade, as in the summer time they are very acceptable in excluding the sun, not withstanding they shed cotton. In a few years when the thousands of trees that are being planted have grown to a respectable size, our city will almost appear a forest, and the intense heat of the summer will be much less felt than either in the past or the present (Sacramento Bee 1857).

The indigenous cottonwood had quickly fallen in popularity owing to the nuisance of its cotton litter and dripping on sidewalks. By 1874, cottonwoods were prohibited by ordinance throughout much of the city, and by 1896 the ordinance was amended to include a larger section of the city (CCM 1874, 1896).

Tree planting and human health. During its early settlement, Sacramento had a reputation as a relatively unsafe and unhealthful place to live. Within the first few years of incorporation, the city had experienced several disastrous fires $(1850,1852,1854)$ and a severe cholera epidemic (1850) (Severson 1973). Because the city was at the juncture of two large rivers, seasonal flooding also had catastrophic consequences during initial decades of settlement (1850, 1852, 1861). Surrounding wetlands provided breeding grounds for insect vectors of such diseases such malaria and encephalitis (Henley 1995). Summer months were characterized by extreme heat, which was generally considered an unhealthful attribute in a city. In addition to its aesthetic contribution, tree planting was widely regarded as a method of cleaning and cooling city air. For example, as early as 1872, the commissioner of health of New York City had already concluded that excessive heat was a chief cause of high death rates during the summer months in New York. He recommended that the board of health pass legislation empowering and requiring the department of parks to plant and maintain trees in all of the streets, avenues, and public places in the city. At about that time, the value of trees to public health was further highlighted in a resolution passed by the New York County Medical Society: "Resolved, that one of the most effective means for mitigating the intense heat of the summer months and diminishing the death-rate among children is the cultivation of an adequate number of trees in the streets" (Solotaroff 1911).

The eucalyptus tree (Eucalyptus globulus) was initially introduced to California from Australia in 1869 as a potential solution to the increasing wood shortages, which resulted in part from profligate harvesting practices by the early settlers 
(Merry 1893). In promoting the multiple potentials of eucalypts, this account also mentions health-related aspects, claiming these trees "decreased the tendency toward malarial fevers wherever they may be planted" (presumably by virtue of their enormous evapotranspiration potential that would dry up nearby stagnating water, thereby reducing the habitat for the disease-carrying mosquito).

Evidence of eucalyptus trees being planted in Sacramento for health reasons dates back to an 1874 planting ordinance, stemming from a recommendation by the president of the board of health at the time (CCM 1874). In 1877, the street commissioner procured 4,000 eucalypts for what could be considered the city's first public tree planting campaign (CCM 1877, 1878).

A horticultural showplace. Arriving from Boston in 1852, James L. Warren established the New England Seed Store, one of the earliest tree businesses in Sacramento. Following the disastrous year of 1852, which had brought the calamities of both fire and flood, Warren urged residents to help revegetate the ravaged city. Far from solely distributing New England varieties, Warren sold a broad range of ornamentals and is allegedly responsible for introducing the now popular camellia (Camellia japonica) to this city (Severson 1973).

Availability of a wide selection of seeds and strong encouragement from nurserymen such as Warren were undoubtedly critical to the early planting fervor in the young city. Although the origin of the sobriquet "City of Trees" remains uncertain, an early reporter to the region had used the term to describe the city as early as 1855 : "Shade trees add much to the beauty of the place; it will be, in a few years, the city of trees. In the great fires that ravaged the place, the large native sycamores were all burned down but so rapid is the growth that the trees set out along the streets already cast quite a shade; in this respect Sacramento looks like a New England city..." (Holden 1987).

The fact that at least two of the larger nurseries had owners from New England (Warren from Boston, and Smith of Smith's Gardens, from Vermont) may have greatly contributed to the early introduction of popular East-coast city trees. By the end of the century, elms were one of the most commonly planted trees along city streets. Early plantings included European elms such as Scotch elm (Ulmus glabra) and English elm (U. procera), as well as North American species such as American elm (U. americana), cork elm (U. thomasii), and Wahoo elm (U. alata). In addition to their availability, elegant appearance, tall height, and generous shade, elms were most likely also favored for sentimental reasons because many of the early settlers were from East coast cities, where elms were widely planted as street trees (Solotaroff 1911).

The diversity of trees and ornamental plants introduced into Sacramento was also undoubtedly aided by the horticultural interests of the affluent and influential Crocker family. In the latter half of the 19th century, Mrs. Crocker owned Bell's Conservatory, an artfully designed, domed structure that housed thousands of different plants from around the world, and whose twin structure now stands in Golden Gate Park in San Francisco. Mrs. Crocker's association with many foreign horticultural centers and her dedication to maintaining Sacramento's beauty through horticulture influenced public interest in the city's growing urban forest (Sacramento Union 1886).

Although Sacramento became the permanent state capital in 1854, landscaping of the capitol grounds did not begin until 1870. With great assistance from the California State Agriculture Society, headquartered in Sacramento, the grounds were planted with 800 trees and flowering shrubs, spanning 200 varieties from all over the world (Schuster 1982). The State Agriculture Society had been founded in 1854 by Warren (the nurseryman), and by 1859 was apparently corresponding with agricultural and horticultural centers in Europe, Asia, Africa, and Australia. Over its long history, the exotic collection of trees on the grounds of the capitol was continuously augmented by commemorative and goodwill plantings, as for instance in 1897, when the Ladies of the Grand Army of the Republic in California and Nevada honored Union veterans of the Civil War by planting trees acquired as saplings from famous battlefields of that war. 


\section{A City of Trees: $1900-1940$}

The turn of the century saw the growth of the "City Beautiful" movement across the United States, a movement largely responsible for the rapid preponderance of tree-lined boulevards and city parks in urban design and planning (Wilson 1989). Correspondingly, Sacramento's parks were growing in number and each typically required improvements, notably, planting trees. These early decades of the 20th century also saw an increase in the level of leisure time afforded to much of the general public, an outgrowth of which was the popularization of such activities as home gardening and recreating in parks. These national trends were evident in Sacramento in the first 40 years of the 20th century, during which time the population increased from approximately 30,000 to 106,000 and area within the city limits grew from 10 to $24 \mathrm{~km}^{2}$ (4 to $\left.9 \mathrm{mi}^{2}\right)$. Additionally, the growth of the progressive movement in politics and, locally, the strong efforts of several charismatic civic leaders, inspired and directed the growth of Sacramento's park system during this formative period. Together, these key conditions set the stage for an active public commitment to beautifying the city through spirited involvement in tree planting.

Early 20th century tree enthusiasts. One of the city's most prominent tree boosters was editor of the Sacramento Bee, C.K. McClatchy (editor 1883 to 1936 ), whose father had founded the newspaper in 1857. Inspired by a visit to the treelined streets of Paris in 1911, McClatchy became an outspoken proponent of trees and heavily promoted the city's reputation as a City of Trees through his publication. His paper published frontpage obituaries for trees killed by vandals, and countless articles and letters decried the felling of trees to make room for continued street widening and establishment of service stations and parking lots: "A street joke in Sacramento runneth as follows: "I see the flag on the Bee is at halfmast.' 'Who's dead?' 'Another oak tree'" (McClatchy 1936). Because newspapers were the primary source of news and information, and McClatchy was extremely influential in the community, his editorials played a critical role in raising public awareness of, and pride in, city trees.
Other civic leaders played an important role. Mrs. J. Henry Miller's impassioned volunteerism exemplified the influence of women on development of the city's urban forest. During 1901, Mrs. Miller waged a lengthy battle to convert a swamp into what is now McKinley Park. Although the city engineer claimed the swamp could not be drained, a reluctant city council purchased the 15 ha (37 ac) site anyway. Mrs. Miller, married to a pioneer banker, became the project's leader. Spending her own money on materials and hosting dinner banquets to repay volunteers and garner support, Mrs. Miller finally succeeded in developing the park. Thirty-four years after the park was completed in 1902, the "Mother of McKinley Park" was honored as a champion for civic betterment (Sacramento Union 1936). Other women, such as Effie Yeaw and Eleanor McClatchy (daughter of C.K. McClatchy) were active champions of the region's native flora and heritage trees.

Fred N. Evans came to work for the city of Sacramento in 1920 as a Harvard-educated landscape architect. He designed many parks, foremost being the 106 ha (263 ac) Land Park. Evans's 1922 plan for Land Park was in the Olmsted tradition, including open greenswards, a nine-hole golf course, and trails for pedestrians and equestrians. As superintendent of the parks department, Evans was responsible for conducting Sacramento's first street tree inventory in 1935, training a competent cadre of city arborists, developing an innovative pest-control program, and promoting planting of desirable tree species.

Through the collective efforts of people such as McClatchy, Miller, and Evans, Sacramento became renown for its greenspace system. In this regard the city was frequently lauded by prominent guests such as William Penn Mott (former director of the National Park Service), who noted:

... the uniformly planted streets with shade trees, the functional and well-maintained parks and their heavy and appreciative use by the public, and the unified activity of the many garden clubs in the city, indicate a fine spirit of civic consciousness on the part of the people living in Sacramento, without which a city soon loses its character and soon becomes just another collection of people (Sacramento Bee 1948). 
Expansion of the park system. The park system as well as the entire urban forest continued to expand after the turn of the century, and the city council finally reacted to multiplying management needs by creating the position of city gardener in 1904. The city gardener was charged with overseeing and managing all work in parks, plazas, and streets of the city, and inspecting all city trees for pest infestations or disease (CCM 1904). To purchase street trees, the city gardener was required to gain approval from the city council because the expenditure was taken out of the city's general funds. In 1905, the city passed an ordinance prescribing the types of trees that may be planted on certain streets, prohibiting the planting of others, and making a violation of this ordinance a misdemeanor.

Owing to continued growth in the number of public parks and their expanding management needs, the city went on to establish the parks department in the 1911 city charter. Headed by a newly created board of parks directors, the responsibilities of the department included control and management of all land and water parks, parkways, squares, and public pleasure grounds; landscaping of city cemeteries; planning and regulating traffic in parks and parkways; and planting and caring for shade trees, shrubs, and plants on streets, public grounds, and around city buildings. By 1914, the charter created the position of superintendent of parks to oversee the above duties.

At this time, the city also decided it needed to develop a park plan for the whole region and hired John Nolen, a student of Frederick L. Olmsted (designer of Central Park in New York City). Interestingly, Nolen, who was located in Cambridge at the largest park planning firm in the country, had Olmsted's son working for him on this project. Completed in 1915, the park plan was never fully implemented, partly due to controversy surrounding the land to be acquired and the inability of the city to devote the funds seemingly required. The resources of the park department became relatively exhausted by large investments in both Del Paso Park (1911) and Land Park. However, ideas from the plan that were later realized include an initial design for the American River
Parkway and the rationale for preserving other creek and river floodplains for public uses.

Early tree planting program. Traditionally, urban forest growth in the public sector had primarily relied on planting and management performed by city employees. In 1923, street tree planting received a permanent boost in community participation as the city inaugurated what would become an annual campaign to promote street tree planting in residential neighborhoods. During the winter, street trees were offered at no cost to any resident who submitted a request. For about 20 years, the city program was coordinated with help from the Junior Chamber of Commerce. Boy Scouts canvassed neighborhoods urging residents to sign request cards that committed them to care for the tree, which was planted by the city. Accounts published in the Sacramento Bee indicate that the first several decades of the tradition yielded an average of approximately 1,000 new trees planted annually. By 1936 , a parks department survey estimated the city had 60,000 trees, 35,000 of which shaded the streets, 24,000 in parks and cemeteries, and 1,000 in alleys. Residents could select from 15 species: Arizona ash (Fraxinus velutina), camphor (Cinnamomum camphora), Chinese elm (Ulmus parvifolia), Siberian elm (U. pumila), Wahoo elm (U. alata), hackberry (Celtis occidentalis), linden (Tilia americana), sweetgum (Liquidamber styraciflua), silver maple (Acer saccharinum), live oak (Quercus virginiana), ornamental orange (Citrus aurantium), pepper tree (Schinus molle), London plane (Platanus acerifolia), oriental plane $(P$. orientalis), and tuliptree (Liriodendron tulipifera) (Sacramento Union 1938a).

Healthful city. Sacramento's maturing tree canopy cover helped change its image from the relatively unhealthful, disease-ridden, and often stiflingly hot city of the 19 th century, to a healthful, tree-lined, pleasant city of the 20th centurya City of Trees. The image of Sacramento as a paradisiacal, resort-style city began to be promoted by 1894 , in a guide to Sacramento County:

A testimonial as to climate would be of no utility without something as to the salubrity or the healthfulness of the locality; for, no matter how balmy and soft might be the breezes, these 
would not be appreciated or sought after, but would be shunned, if they carried on their seductive breath the germs of disease. Statistics furnished by the State Board of Health prove that Sacramento is the second healthiest city in the United States.... The palm in the city is to be seen at its perfection-and it is everywhere, too. In many places through town it adorns the sidewalks, like the other shade trees for which Sacramento is noted (McClatchy 1894).

Along the same vein, pamphlets distributed by the chamber of commerce during the early 1920 s boasted of the city's elm-arched boulevards, well-shaded thoroughfares and everblooming gardens teeming with semi-tropical plant life (Chamber of Commerce 1920-1930). Trees had become a major icon for the city's newly emerging image: "The crowning glory that is Sacramento's-her glorious shade trees, are glorious because the city looks out for them with as much care and anxiety as a fond parent does for her offspring" (Sacramento Bee 1939).

Catastrophic windstorm. In 1938, a severe storm hit Sacramento, uprooting an estimated 644 trees and loosening the roots of about 300 to the extent that they had to be removed. The city lost about $6 \%$ of the 15,500 trees within old city limits, and 280 houses were damaged (Sacramento Union 1938b). Unfortunately, many of the city's oldest and most stately elms were lost. According to complaint letters published in local newspapers (Sacramento Union 1938c), many long-time residents declared that much of the damage to the elms (most of which were 70 years old) was due to the modern method of trimming trees. In the past, trees had been trimmed from the top, allowing them to branch out. During the 1930s, trimmers began removing limbs from the bottom to minimize traffic and pedestrian hazards, a practice that apparently tended to make trees top-heavy and unable to withstand the pressure of strong winds. Root systems that were cut off or damaged during street widening and paving of roadways were also considered responsible for tree toppling.

The natural disaster of 1938 catalyzed changes in the city's tree program and in local perceptions of its large trees. Management at- tention focused on the issue of spacing because many of the trees that had fallen had been spaced

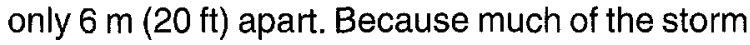
damage had resulted from falling trees and limbs, trees-particularly the large elms-were now sometimes regarded as a menace.

Additional tree-related complaints included the blockage of sunshine to backyards, which prevented growth of grass and flowers, the constant sweeping necessary to keep sidewalks clear of falling twigs and leaves, broken sidewalks from root growth, and among store owners, protests that the trees covered their signs. Many residents expressed a desire for smaller, cleaner trees, spaced further apart to admit a little "healthy" sunshine. They argued these improvements would be safer and less expensive for the city and would make the streets look much cleaner and more beautiful. Trees noted as desirable among residents included smaller-sized trees such as the ash, acacia, birch, camphor, and linden. The same elms that had traditionally been the pride and joy of most city residents were now considered by some as good for parks but not in front of homes.

Interestingly, however, removal of some large elms following the storm angered a group of residents who were protective of the city's heritage. In 1939, the seemingly indiscriminant removal of healthy elms compelled this group to call for more democratization of urban forest management. They demanded that the city council resume control over tree removal permits, which had been solely the responsibility of the parks superintendent. Citizens claimed that too much power belonged to one man, who had to consider no other opinions when accepting or rejecting applications for tree removal permits. Much to the chagrin of these residents and the media, the city attorney defended the system, responding that the authority over tree permits was, by city charter, exclusively with the parks superintendent.

\section{Post-War Boom: 1940-1955}

World War II had an important indirect and unexpected effect on the residents of Sacramento: the gas and tire shortages of 1940 encouraged city residents to stay within city limits and to explore 
further the recreational possibilities of their own city (Sacramento Bee 1940a). Park visitation increased dramatically and the city invested more in park beautification, principally by expanding the system of urban parks and planting more trees within them and along city streets (Figure 3).

Between 1940 and 1955, the city expanded from 36 to $98 \mathrm{~km}^{2}$ (14 to $38 \mathrm{mi}^{2}$ ), and the population increased from about 106,000 to 170,000 . The number of city street and park trees nearly doubled, growing from 60,000 to 100,000 , or approximately one tree for every two residents. This ratio was important to Sacramento residents because it surpassed that found in Paris, a city world-renowned for its tree-lined streets. At that time, Paris claimed it had 400,000 trees, which, although a larger total figure, amounted to about one tree for every ten residents (Sacramento Bee 1953). Funding for Sacramento's tree care program did not keep pace with the growing tree population. The percentage of total city budget allocated to the tree program dropped from $2 \%$ in 1940 to $1.75 \%$ in 1955 . Management during this era centered on tree protection: reducing depredations of pests, diseases, and wind storms.

Waging war on tree pests and diseases. In the 1930 s and 1940s, advances in technology boosted efforts to control the pests and diseases that continually threatened the health of Sacramento's maturing tree canopy:

The Park Department for many years used spraying material principally to shower infected trees with a solution of arsenate of lead. A few years ago however, pest control director Charles Haenggi devised a machine which dusts the trees with a poison powder compound. The 9-inch blower, generated by a 40 -horsepower motor, is capable of throwing the powder 150 feet into the air. This allows the workers to reach the tops of the tallest trees. Approximately 20,000 pounds of exterminating material are used annually by the Department (Sacramento Union 1940).

In $1945,50,000$ of the 65,000 city-owned shade trees were sprayed each year (Figure 4), some

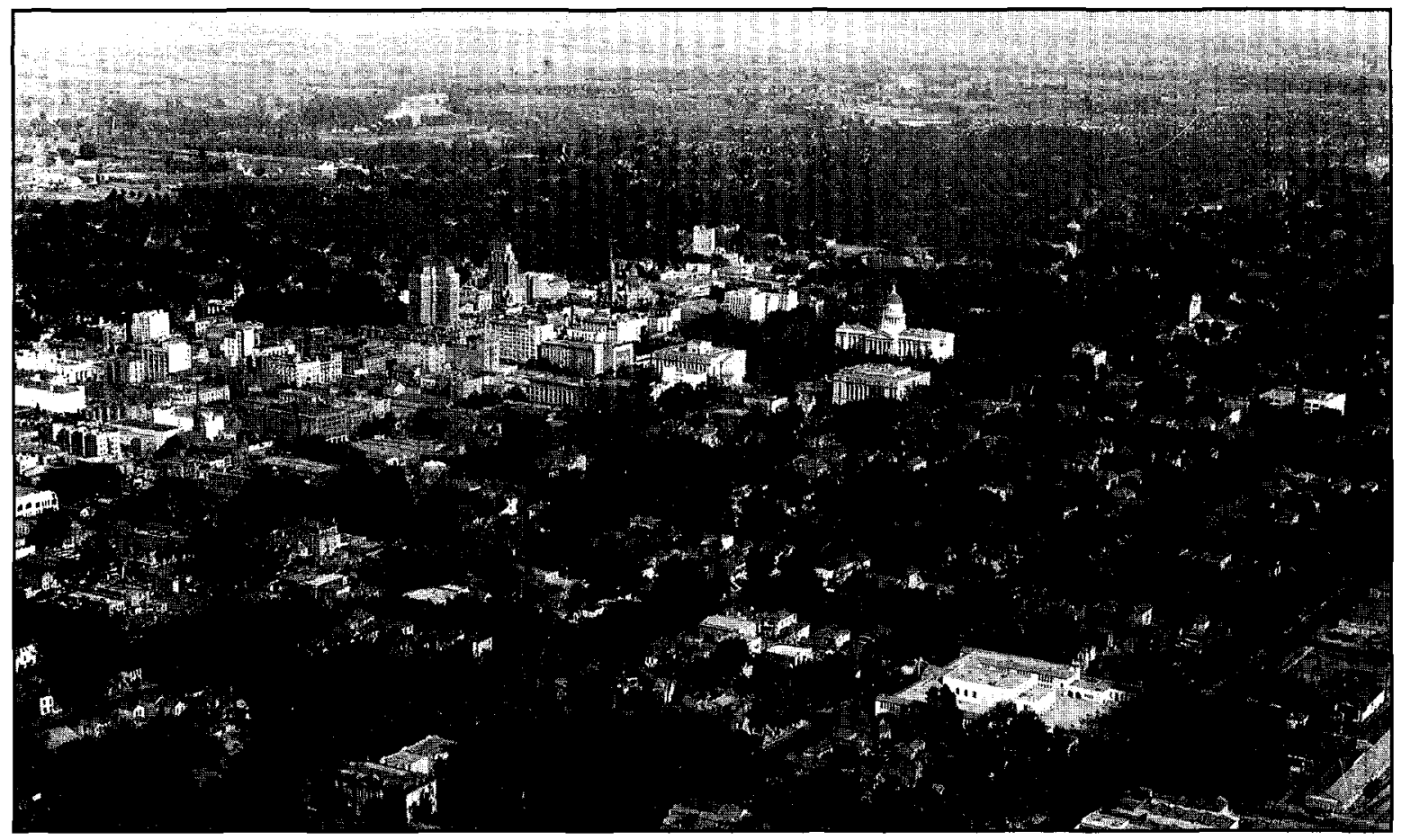

Figure 3. By 1950, much of Sacramento was shaded by a mature urban forest canopy (photo courtesy of the Sacramento Archives and Museum Collection Center [SAMCC]). 
two or three times to keep them free from insects and disease (Sacramento Union 1945). Although more effective chemicals became available and application technologies advanced, pest problems continued to hinder the health of Sacramento's urban forest. City council records indicate that in 1951 the city's tree division was still purchasing an arsenal of chemicals: $2,268 \mathrm{~kg}(5,000 \mathrm{lb})$ of basic lead arsenate, $1,270 \mathrm{~kg}(2,800 \mathrm{lb})$ of wettable benzene hexachloride, $1,360 \mathrm{~kg}(3,000 \mathrm{lb})$ of wettable DDT, $1,905 \mathrm{~kg}(4,200 \mathrm{lb})$ of copper sulphate, and $4,173 \mathrm{~kg}(9,200 \mathrm{lb})$ of calcium arsenate dust (CCM 1850-1960). The parks department extended its elm leaf beetle control program to infested trees on private property: "We found that one infected tree on private property soon would infect our own trees. Now, whenever we discover a diseased privately owned tree we treat it just as we do our own" (Sacramento Union 1940).

It is somewhat ironic that during a time when Sacramento was considered one of the nation's most healthful cities, partly by virtue of its trees, large amounts of potentially toxic chemicals were used to sustain tree health. Although one can only speculate as to the effects of these chemicals on the health of humans and wildlife, some adverse impacts seem probable.

Management reacts. Severe windstorms in 1941 and 1950 forced the city to remove hundreds of trees deemed ruined or unsafe. Additionally, of the 40,000 trees that lined city streets in 1941, the parks department estimated that 5,000 to 7,000 were poor specimens that should be removed and that many were spaced too

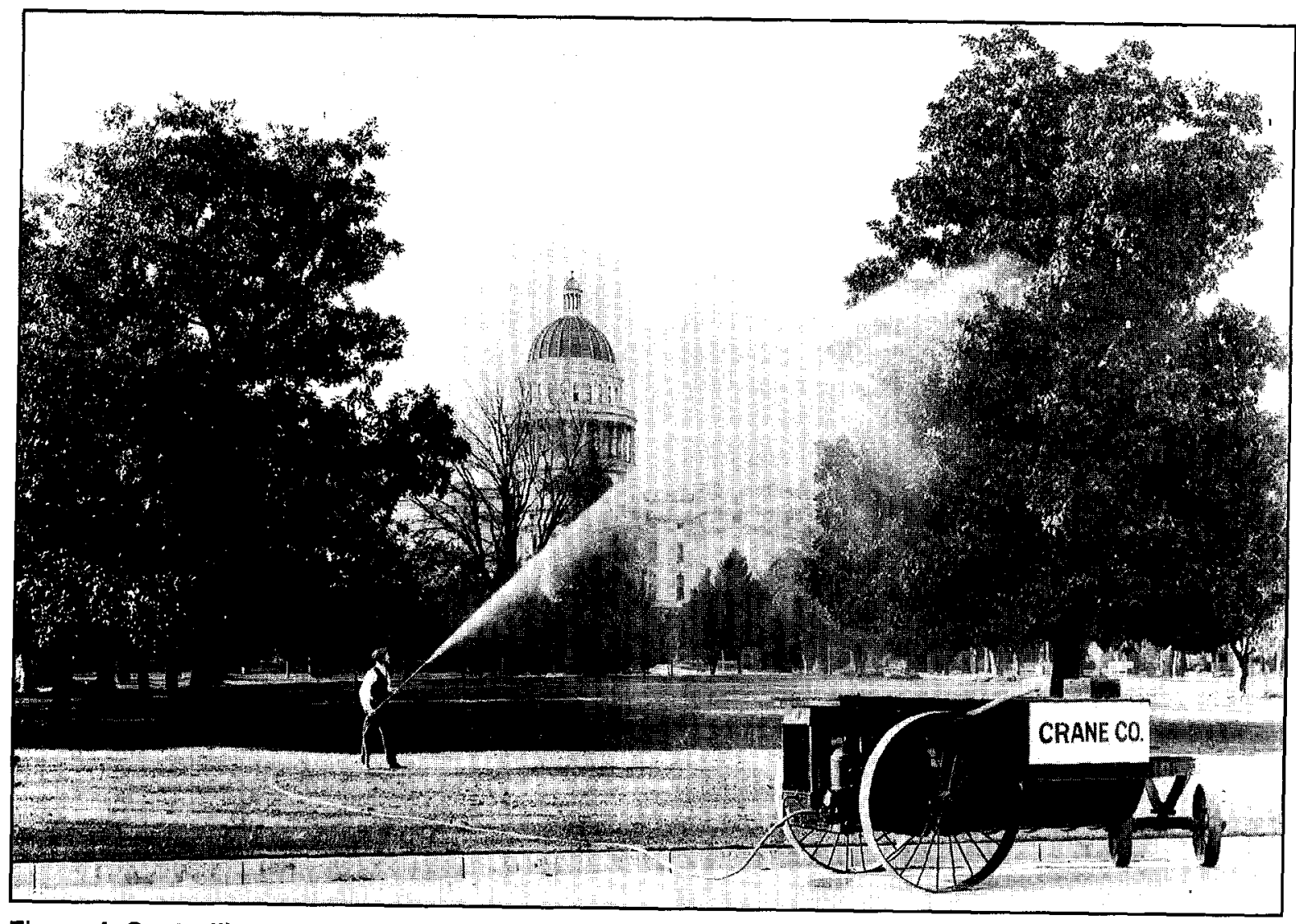

Figure 4. Controlling pests in the urban forest, circa 1930s. The city's tree division waged an all-out war against unrelenting pests that threatened the urban forest. By 1940, the city was using about 20,000 pounds of chemicals each year for pest control (photo courtesy of the Betty Jane Powell collection [SAMCC]). 
closely together to maintain adequate health. In accordance with their findings, the department developed a long-range program for eliminating aged, unhealthy trees and replacing them with young ones. A dozen trees removed at this time were also cleared to make room for traffic lights, as the city continued to expand and modernize and more of its residents began to own cars. Large-scale tree removals met public complaints from the more ardent tree-loving residents, who claimed that, as in the aftermath of the 1938 storm, the city was removing too many of its old trees.

In 1947, Superintendent of Parks William Carroll noted that careless location of trees during the previous decades would cost the city more than $\$ 250,000$ in tree removal costs and mitigation of damage to sidewalks, streets, and gutters (Sacramento Bee 1947). New planting rules regarding spacing and placement were adopted to curb future tree removal and storm damage costs. The necessity for these regulations seemed further reinforced when the 1950 storm sent 65 trees toppling onto streets, cars, and houses. By 1949 , about 1,800 street trees were planted and 450 removed each year. Carroll noted, "We want a tree which will give us the least trouble and the most shade" (Sacramento Union 1949). Pistache (Pistacia chinensis), zelkova (Zelkova serrata), and Modesto ash (Fraxinus velutina 'Modesto') were regarded as disease- and storm-resistant species. Also, the hardpan in many parts of the city influenced tree selection. Trees of the same species were usually planted in the same block, but not in too large an area. "We do that so if a disease strikes it won't clean the entire area of trees" (Sacramento Union 1949).

Public protests over the lack of democratization regarding the fate of the city's trees continued. Angered at what they considered to be an unfair system that typically favored commercial interests, the Sacramento Science Teachers' Association recommended to the city council that steps be taken to place more authority into the hands of civic representatives, arguing:

Our city is noted for its beautiful shade trees and it is the duty of the citizens to see that they are preserved. We suggest that the sole power for determining whether a tree be removed be taken out of the hands of one person and placed into the hands of a committee made up of representatives from the different civic organizations of the city. We, as science teachers, constantly present to the future citizens of our city a conservation program in our schools. If commercial influences are always to outweigh moral and aesthetic influences, then the teaching of conservation in our schools is futile ( $\mathrm{SaC}$ ramento Bee 1940 b).

In response to rising public complaints, the city did change its permit review process slightly. New rules required the parks superintendent to take two weeks to review a case, to ensure that an adequate assessment had been made concerning alternatives to tree removals.

\section{Development, Disease, and Declining Budgets: 1955-1995}

During this 40-year period, Sacramento grew into a city with a metropolitan region of more than $1,000,000$ people. The city's population alone increased from 170,000 to 394,000 , and the area within the city limits increased from 98 to $290 \mathrm{~km}^{2}$ (38 to $111 \mathrm{mi}^{2}$ ). Not surprisingly, the number of city trees also increased from 100,000 in 1955 to about 150,000 in 1990 . The percentage of total city budget devoted to the tree program dropped, from 1.75 in 1955 to 0.74 in 1994. Managers of the publicly owned forest were faced with dwindling resources to manage an ever-expanding tree population. To exacerbate the situation, other problems arose including insufficient tree planting in new developments, Dutch elm disease, and an increasingly senescent forest.

Smaller trees and treeless subdivisions. The early part of this period saw a considerable increase in the number of tree removals permitted in the city, primarily to accommodate the expansion in commercial developments and infrastructure, such as street widening and utility works. As old trees were removed, younger, smaller-growing trees were often planted in their place. These replacement plantings increased the diversity of certain older city sectors that were previously relatively even-aged and homogenous in species composition. However, during the 1950 s and 1960 s, relatively few tree species were 
used in new plantings. For instance, the annual planting program had reduced the variety of trees it gave away, primarily using three species: Modesto ash, zelkova, and Chinese elm. Fruitless mulberries (Morus alba, male form) and sweetgums (Liquidamber styraciflua) were favored in new subdivisions, although trees were generally not being heavily planted in these areas (Fitch 1995). The plethora of ash trees planted during this time would later prove problematic, as parasitic mistletoe preferentially attacked these trees.

Treeless subdivisions became increasingly common as Sacramento expanded in the $1950 \mathrm{~s}$ (Figure 5). A 1956 article in the Sacramento Bee highlighted this issue and compelled the city council to request a review of its street tree ordinance with the intent of enacting a stricter ordinance requiring tree planting in the newer areas of the city (Sacramento Bee 1956). In 1960, the ordinance was passed (Sacramento Bee 1960).

We hypothesize that the relative reduction in tree planting in the newer developments may be, to some degree, tied to the popularization of air conditioning at this time. Owing to Sacramento's extremely hot summers, popularization of this technology grew quickly in the mid 1950s. In 1959 , sales of room air-conditioning units had soared $92 \%$ over the previous year and resulted in shifting the peak electricity usage season from winter to summer months (Sacramento Municipal Utility District 1959). Modern air conditioning reduced local dependence on trees for space cooling and may have lowered public value of trees in these newer subdivisions.

New volunteers. To provide an avenue for public participation in urban forestry, in 1981 the mayor and the county board of supervisors called together more than 125 civic, business, and community leaders to introduce the concept of a community-based nonprofit organization to be called the Sacramento Tree Foundation (STF). For 11 months, more than 50 volunteers worked to develop financing, program goals, and future plans for the organization. On March 7, 1982, California's Arbor Day, the Sacramento Tree Foundation was officially launched. In its early years, the foundation coordinated several street, park, and school planting programs with support from the Sacramento County tree coordinator and a 25-member technical advisory committee. Increasingly, the foundation extended beyond tree planting, to highlight stewardship and care of the trees.

In 1990, a citizen's action group called Trees for Tomorrow officially joined STF and created the goal of planting $1,000,000$ trees in the county by the year 2000 . Soon after, the Sacramento Municipal Utility District (SMUD) initiated a partnership with STF, creating a new entity, the Sacramento Shade Tree Program. The Sacramento Shade Tree Program agreed to sponsor half of the million trees goal, by planting 500,000 energy-saving shade trees by the year 2000 . Approximately 275,000 trees were planted in residential yards by 1998 . Sacramento Shade is having a substantial impact on the region's urban forest and the practice of urban forestry. Not only are large numbers of trees being planted and maintained by residents on private property, but STF has emerged as a primary source of information on tree care for the public. In Sacramento, "urban forestry" no longer refers to management of just street and park trees. Rather, the term refers to all trees and acknowledges the residents who are so attentive to tree health.

Partners combat dying elms. In 1982, the city initiated a 20-year Elm Tree Reforestation Program, with the goal of replacing 200 of the city's 5,000 declining elm trees each year. Ironically, Dutch elm disease (DED) was not present in Sacramento at the time, but illness and mortality of elm trees (as well as the knowledge that DED would eventually reach there) led to increasing concern on the part of both the city tree services division and the citizenry. Replacement trees would be more disease-resistant species, principally those that would also reach tall height at maturity and produce shade similar to that produced by elms (valley oak, European beech [Fagus sylvatica], ginkgo [Ginkgo biloba]) (Fitch and Bramble 1984).

To meet increasing citizen complaints that the city was removing healthy trees to reach its quota of 200 trees per year, the city council created a street tree task force in 1986. Charged with reviewing the elm tree reforestation program and 
providing guidelines for a new planting program, the group concluded that the reforestation program should be discontinued and replaced with a formal tree management plan (eventually, this became the Urban Forest Management Plan).

Dutch elm disease was first detected in California in 1974 (at a small community in Sonoma County). In a proactive response, Sacramento city and county issued DED-related ordinances, but it was not until 1990 that the disease reached the city. Once DED reached Sacramento's forest, response to the disease took several forms. Of primary importance was the formation of a community action group after state support for a DED control program dissolved in 1993. The Save The Elms Program (STEP) was primarily composed of down-

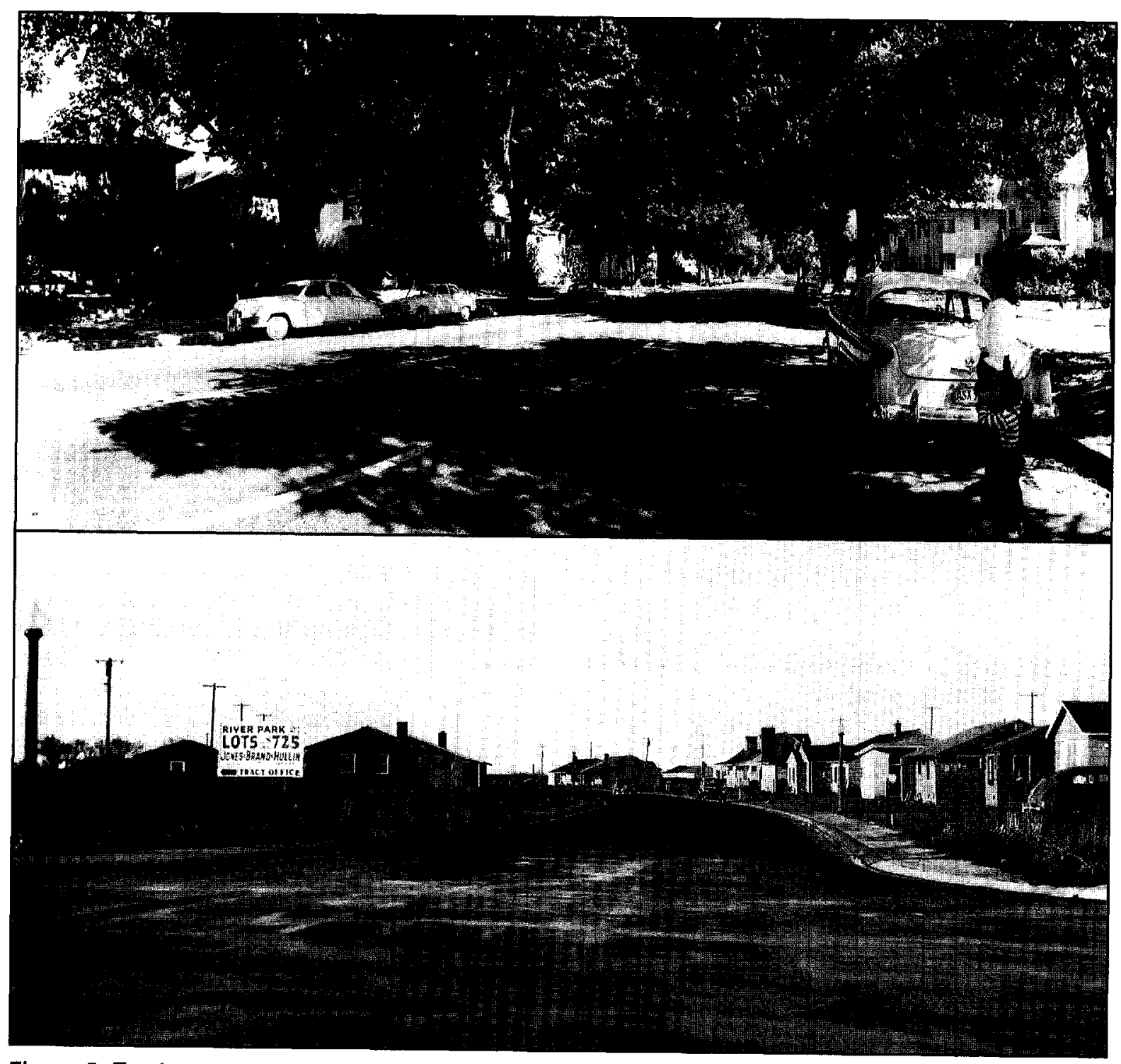

Figure 5. Treeless subdivisions characterized the city's explosive growth in the 1950s and 1960s and were a sharp contrast to the verdure found in the older sector of Sacramento (top photo courtesy of the Sacramento Bee collection; bottom photo courtesy of the Eugene Hepting collection [SAMCC]). 
town residents (where most of the threatened elms are located) dedicated to active monitoring and caring for threatened elms. STEP joined forces with the Sacramento Tree Foundation and currently has 150 trained volunteers who inspect Sacramento's elms on a biweekly basis during the summer (Figure 6). STEP and the city tree program collaborate to educate the community about proper elm care, the importance of early diagnosis, and the planting of disease-resistant varieties. The city has instituted mandatory testing of all diseased elms, to verify causes of mortality and track spread of the disease. Additionally, STEP, the city, and university researchers are testing the effectiveness of integrated pest management techniques for control of the elm leaf beetle.

Current management issues. According to a 1988 tree inventory, the asset value of all publicly owned trees was estimated to be $\$ 300$ million (Sacramento Tree Services Division 1988). At the time, Sacramento's public tree resource consisted of about 150,000 trees representing more than 350 different tree species. The most common genera were Fraxinus ( $11 \%$ of all public trees), Platanus (9\%), UImus and Zelkova ( $8 \%$ ), Liquidamber (4\%), and Morus (3\%). Ash, plane, and elm trees represent the majority of the city's oldest trees and require proportionately more maintenance than other trees. In 1988, the city

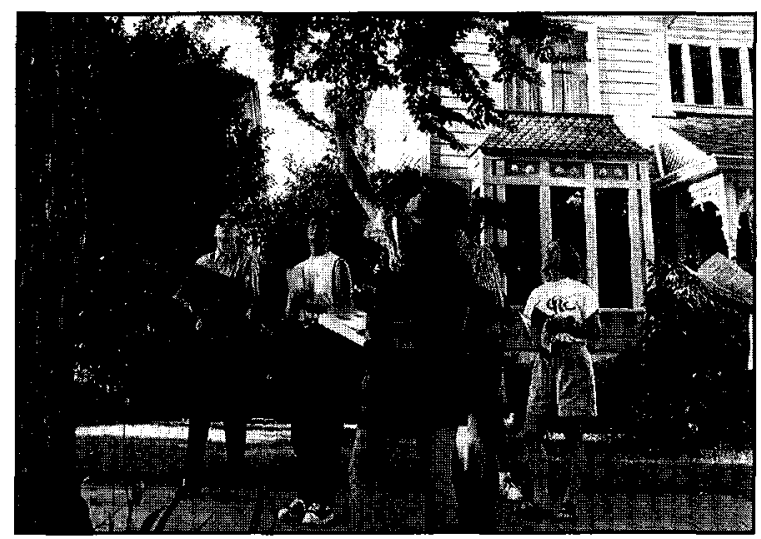

Figure 6. An emerging system of urban forest management includes active public participation. For example, Save The Elms Project has a cadre of over 150 trained volunteers who monitor trees for signs of Dutch elm disease (photo courtesy of the Sacramento Tree Foundation 1995). employed 24 full-time tree trimmers, and the typical tree was inspected and pruned once every 20 years. This inspection and pruning cycle is four times longer than the recommended professional standard. Inadequate routine pruning and maintenance have increased the incidence of decay, deadwood, and heavy limbs, thereby magnifying storm damage costs (Wolfe Mason Associates 1992).

To reduce management costs in the face of declining budgets, the city council passed an ordinance in 1990 placing a tree maintenance moratorium on the 57,500 trees located within the private maintenance strip (a utility access easement running approximately $4 \mathrm{~m}[12.5 \mathrm{ft}]$ back from the street curb or edge of pavement), relinquishing their care to property owners. This decision resulted in a higher allocation of care for many of the large shade trees in the older parts of Sacramento, but increased the vulnerability of the maintenance strip trees to irregular maintenance, storm damage, and attacks from insects and disease.

In 1992, the consultant-prepared Urban Forest Management Plan was completed (Wolfe Mason Associates 1992). Key issues identified by the report included inadequate services relating to maintenance strip trees and the 20-year pruning cycle; plantings in newly developed areas; optimization of limited resources for tree programs; encouragement of neighborhood involvement; maintenance of urban forest health; and secured funding. The plan provided costs for alternative management strategies that reduce the inspection and pruning cycle, as well as design, planning, and management recommendations.

Growing concern about the apparently deteriorating condition of Sacramento's urban forest and the need for public support led Sacramento city and county governments and the Sacramento Tree Foundation to create the Sacramento Urban Forest Task Force. An alliance of local businesses, nonprofit organizations, and the government, the task force considered 18 components of the urban forest and defined indicators of sustainability for each component. In 1996, the group published a report recommending action steps for sustainable management of trees 
on public and private lands (Sacramento Urban Forest Task Force 1996).

Collaborative efforts such as the State of the Urban Forest Report 1996 (Sacramento Urban Forest Task Force 1996) have led to new associations among a wide spectrum of citizens, organizations, and businesses. As a result, partners are creating alternative ways of nurturing Sacramento's urban forest. For example, the city tree division maintains its prominent role managing the very visible street and park tree resource. However, STEP volunteers and university researchers are now assisting through Dutch elm disease monitoring and testing of nontoxic controls for elm leaf beetle. In 1996 STF collaborated with the city to deliver a mistletoe abatement program called "Keep It for Kissing and out of the Trees." Approximately 300 households removed mistletoe from over 600 trees using this pole-saw loan program. Organizations such as the STF and SMUD are working with residents at a grassroots level to inspire a sense of environmental stewardship through citizen forestry. Local STF projects, which include neighborhood groups, redevelopment agencies, flood control agencies, businesses, schools, and health-care organizations, are increasing public awareness and broadening the base of support for urban forestry.

\section{Conclusion}

Sacramento's urban forest has evolved over the course of almost 150 years, responding to a host of natural and cultural processes. Native riparian vegetation and upland oak trees defined the composition of the incipient urban forest. As many of these trees were lost during initial settlement, the character of Sacramento's early urban forest eventually became defined by city-organized tree plantings. Local government was instrumental in establishing the first trees through funding of street, park, and levee plantings, as well as prescribing and banning certain species. In the mid 19th century, state government became an author of Sacramento's treescape through construction of Capital Park, a showplace that attracted the attention of horticulturists from around the world.
In the early decades of the 20th century, Sacramento's treescape was influenced by a wide spectrum of individuals, civic organizations, clubs, and elected officials. The annual planting campaign that involved youth (Boy Scouts), business (chamber of commerce), and government (parks department) exemplified how a civic-minded spirit fostered public regard for the city's verdure. Perpetuating the urban forest became a community responsibility and in turn, the city's garden settings and its healthy environment became sources of civic pride.

Sacramento's maturing urban forest began to pose serious management challenges in the 1930 s and 1940 s. Periodic windstorms and insect infestations elicited public outcries to which tree managers and city officials reacted, chiefly by instituting new programs and regulations aimed at reducing tree mortality and lowering management costs. Controversy over tree removal policies was vitriolic at times. Despite the mounting cost of maintaining an aging urban forest, public support remained firm as the city's shade trees continued to be regarded as Sacramento's crowning glory.

Public involvement in tree planting declined during the era of rapid population growth following World War II and, as funds for the municipal tree program gradually diminished, Sacramento's ability to sustain its municipal urban forest began to erode. Historically, Sacramento's urban forest served the needs of residents by providing comfort and beauty. Today, as the region grows and its population becomes more diverse, the urban forest is expected to produce more benefits. Multiple managers are interested in nurturing "their" trees to clean the air and water, conserve energy, increase employment, produce food, restore riparian habitats, reduce skin cancer, and enhance biodiversity. At the same time, the public has become more aware of certain costs associated with trees, such as production of pollen and ozone-forming biogenic hydrocarbons, fuel load and fire threat, green-waste disposal, water use, and damage to infrastructure. Managers face the challenge of finding alternative design and management strategies that will sustain net benefits over the long term. 
Sacramento's urban forest has become an integral component of the city's heritage, and Sacramentans have developed an abiding affection for the leafy shade of their mature tree canopy. They have waged war on pests that threatened their trees and lamented the loss of each venerable elm, plane, and oak. They have planted and cared for their trees with religious zeal. Now, new partnerships are forming and innovative solutions to nurturing Sacramento's urban forest are beginning to leave their mark on the city's treescape. Whether or not these strategies prove successful, their very existence is a tribute to Sacramento's continuing arboreal heritage and the critical role public involvement has played in this legacy.

\section{Literature Cited}

Chamber of Commerce. 1920-1930. Folio of annual Sacramento Chamber of Commerce literature. Sacramento Archives and Museum Collection Center, City of Sacramento, CA.

City Council Minutes. 1853-1960. Folio of annual council minutes. Sacramento Archives and Museum Collection Center, City of Sacramento, CA.

Daily Democratic State Journal. 1855. February 13.

Dobbins, G. 1980. Sacramento: City of Trees. Sacramento Bee. Sacramento, CA.

Fitch, M.J. 1995. Personal communication, Oct. 14.

Fitch, M.J., and J. Bramble. 1984. Sacramento-City of Trees. Arboric. J. 8:157-165.

Henley, J. 1995. Personal correspondence. Oct. 10.

Heritage Oaks Committee. 1976. Native oaks: Our valley heritage. Sacramento County Office of Education. Sacramento, CA

Holden, W. 1987. Sacramento: Excursions into Its History and Natural World. Two Rivers Publishing Company, Sacramento, CA.

Kane, J.N., and Alexander G.L. 1979. Nicknames and sobriquets of U.S. cities, states, and counties. Scarecrow Press, Metuchen, NJ.

Lawrence, H.W. 1993. The neo-classical origins of modern urban forests. For. Conserv. Hist. 37:2636.

McClatchy, C.K. 1894. A Guide to the Resources of Sacramento County. Sacramento Chamber of Commerce, Sacramento, CA.

McClatchy, C.K. 1936. Private Thinks by C.K. The Scribner Press, New York, NY.

McClatchy High School. 1948. Park Grants of John August Sutter, Jr. Nugget Press, Sacramento, CA.
McPherson, E.G. In press. Structure and sustainability of Sacramento's urban forest. J. Arboric.

McPherson, E.G., and R.A. Haip. 1989. Emerging desert landscape in Tucson. Geogr. Rev. 79: 435-449.

McPherson, E.G., D.J. Nowak, P.L. Sacamano, S.E. Prichard, and E.M. Makara. 1993. Chicago's Evolving Urban Forest: Initial Report of the Chicago Urban Forest Climate Project. USDA For. Serv. Northeast For. Exp. Sta. Radnor, PA.

Merry, T.B. 1893. Australasian Arboriculture. In Transactions of the State Agriculture Society of 1893. State Agriculture Society, Sacramento, CA.

Nowak, D. 1993. Historical vegetation change in Oakland and its implications for urban forest management. J. Arboric. 19:313-319.

Pierce, R.A., and J.H. Winslow. 1979. H.M.S. Sulphur on the Northwest and California Coasts. Limestone Press, Kingston, Ont.

Sacramento Bee. 1857. Local news: City gardening. Mar. 8.

Sacramento Bee. 1938. Letters to the editor: Tree topping urged. Feb. 20.

Sacramento Bee. 1939. Relentless war is waged to preserve glorious verdure. Aug. 31.

Sacramento Bee. 1940a. John Sutter couldn't foresee today's gasoline shortage but he did provide parks near Sacramentans' homes. Mar. 23.

Sacramento Bee. 1940b. Teachers favor civic clubs as tree guardians; city council is asked to rescind power given to park chief. Mar. 15.

Sacramento Bee . 1947. City plants trees for residents. Dec. 7.

Sacramento Bee. 1948. Praise for Sacramento. Apr. 25.

Sacramento Bee. 1953. Paris' profusion of trees is exceeded in Sacramento. Aug. 10.

Sacramento Bee. 1956. City's growth menaces trees, key to beauty. June 28 .

Sacramento Bee. 1960. City council adopts tree ordinance. Dec. 9.

Sacramento Municipal Utility District. 1959. Annual report. SMUD, Sacramento, CA.

Sacramento Tree Services Division. 1988. Species code report. City of Sacramento Department of Parks and Community Services, Sacramento, CA.

Sacramento Union. 1886. Sacramento's pride. Aug. 12.

Sacramento Union. 1936. Mother of McKinley Park to be honored tonight. Sept. 5.

Sacramento Union. 1938a. Scouts to urge tree planting. Feb. 25. 
Sacramento Union. 1938b. 'Old' city loses 945 trees in storm. Feb. 18.

Sacramento Union. 1938c. Tree topping is urged to prevent uprooting here. Feb. 19.

Sacramento Union. 1940. City is nursemaid to 40,000 trees. May 4.

Sacramento Union. 1945. City announces schedule for spraying trees. From G. Dobbins's collection of newspaper articles, exact date unknown.

Sacramento Union. 1949. Tree planting big business in California. Mar. 6.

Sacramento Urban Forest Task Force. 1996. State of the Urban Forest Report 1996. City of Sacramento. Sacramento, CA.

Sanders, R.A. 1984. Some determinants of urban forest structure. Urb. Ecol. 8:13-27.

Schuster, M.J. 1982. Capitol Park Trees: A User's Guide. Peterson Publishing, Sacramento, CA.

Severson, T. 1973. Sacramento: An Illustrated History. California Historical Society, Sacramento, CA.

Solotaroff, W. 1911. Shade Trees in Towns and Cities. Wiley, New York, NY.

Taylor, B. 1949. Eldorado. In Cleland, R.G., and O. Lewis (Eds.). California's Centenary Celebrations 1946-50. Knopf, New York, NY.

Tugel, A.J. 1993. Soil Survey of Sacramento County, California. USDA SCS, Washington, DC.

Wilson, W.H. 1989. The City Beautiful Movement. John Hopkins Press, Baltimore, MD.

Wolfe Mason Associates. 1992. Sacramento Urban Forest Management Plan. City of Sacramento Parks and Community Services. Sacramento, CA.

Acknowledgements. We appreciate helpful reviews of an earlier version of this manuscript by Dr. Henry Lawrence (Edinboro University, Edinboro, Pennsylvania), James Henley (City of Sacramento), Martin Fitch (City of Sacramento), Ray Tretheway (Sacramento Tree Foundation), and Paula Peper (USDA Forest Service). Jason Webber and John Lichter provided research assistance.

USDA Forest Service

Pacific Southwest Research Station

Western Center for Urban Forest Research and Education

clo Department of Environmental Horticulture

University of California

Davis, CA 95616
Résumé. Au cours des 150 dernières années, une combinaison de processus culturels et naturels ont modifié Sacramento de Ville des plaines à Ville des arbres. Cet article décrit comment les nombreux penseurs de l'aménagement forestier de Sacramento ont affecté la santé, la gestion et la perception publique des arbres de la ville. Les autorités municipales ont ordonné très tôt la plantation d'arbres de rues et de parcs et ont aussi banni par réglementation les espèces nuisibles. Durant la première moitié du 20 e siècle, la participation des organismes privés à la plantation d'arbres de rues et à leur préservation a permis d'accroître la conscience et la fierté du public. Les grands arbres ombrageant les rues de la ville sont devenus le symbole de cette communauté, fréquemment appelés le "Joyau de la couronne de Sacramento ". Plus récemment, l'intérêt porté à la santé des arbres des rues, associé à la restriction des fonds municipaux pour l'entretien des arbres, a fait naître de nouveaux partenariats qui impliquent des volontaires formés pour la surveillance de la maladie hollandaise de l'orme, des résidents dont l'énergie est au service de la conservation des arbres plantés sur les propriétés et un groupe d'intervention public pour développer une politique de recommandations pour perpétuer l'héritage de «Ville des arbres » de Sacramento.

Zusammenfassung. Über einen Zeitraum von 150 Jahren entwickelte sich durch eine Kombination von kulturellen und natürlichen Prozessen aus Sacramento als einer Stadt der Steppe eine Stadt der Bäume.Diese Studie beschreibt, wie viele Autoren aus den Bereich der Landespflege in Sacramento die Gesundheit, das Management und die öffentliche Einstellung zu Stadtbäumen beeinflußt haben. Die Stadtverwaltung leitete die frühen Straßen- und Parkbaumpflanzungen, wobei durch Verordnungen problematische Baumarten verboten wurden. Während der ersiten Hälfte des 20. Jahrhunderts erwuchs aus der Teilnahme von privaten Organisationen an der Baumpflanzung und Pflege ein öffentliches Bewußtsein und Bürgerstolz. Die großen schattenspendenden Srarßenbäume wurden zum Herz der Gemeinde und wurden öfters als das "krönende Juwel von Sacramento" beschrieben. In der letzten Zeit hat die Betroffenheit über die Gesundheit der Straßenbäume in Verbindung mit sinkendem Etat für die öffentliche Baumpflege neue Partnerschaften hervorgerufen, die ausgebildete Freiwillige bei der Kontrolle der Ulmenkrankheit einsetzen, Anwohner über energiesparende Baumpflanzungen unterrichten und die Gründung einer Bürgerinitiative zur Entwicklung von Richtlinien/ Empfehlungen, um den Ruf von Sacramento als Stadt der Bäume aufrecht zu halten. 